\title{
Educational projects - A way of exercising for the teaching profession
}

\author{
Magda Petrescu
}

Teacher Training Department, West University of Timișoara, Romania

\section{abstract}

One of the ways to learn and evaluate effectively is to carry out an educational project (individually or in a group); in which case, the teacher becomes a facilitator of learning and training. Materials and methods. This study is based on five projects elaborated by the students from the Faculty of Physical Education and Sports, West University of Timișoara (master studies), enrolled in the Teacher Training Program. Results. Most groups of projects start from an educational need/problem and, during the process, students establish goals and activities for the implementation of the educational project and estimate the necessary resources. This paper is just a descriptive presentation of the way future sports teachers approach educational projects.

Key words: effective learning, educational project, master students.

\section{article details}

Article statistics: Word count: 3,975; Tables: 2; Figures: 4; References: 8

Received: June 2020; Accepted: August 2020; Published: November 2020

Full-text PDF: http://www.balticsportscience.com

Copyright @ Gdansk University of Physical Education and Sport, Poland

Indexation: Celdes, Clarivate Analytics Emerging Sources Citation Index (ESCI), CNKI Scholar (China National Knowledge Infrastructure), CNPIEC, De Gruyter - IBR (International Bibliography of Reviews of Scholarly Literature in the Humanities and Social Sciences), De Gruyter - IBZ (International Bibliography of Periodical Literature in the Humanities and Social Sciences), DOAJ, EBSCO - Central \& Eastern European Academic Source, EBSCO - SPORTDiscus, EBSCO Discovery Service, Google Scholar, Index Copernicus, J-Gate, Naviga (Softweco, Primo Central (ExLibris), ProQuest - Family Health, ProQuest - Health \& Medical Complete, ProQuest - Illustrata: Health Sciences, ProQuest - Nursing \& Allied Health Source, Summon (Serials Solutions/ProQuest, TDOne (TDNet), Ulrich's Periodicals Directory/ulrichsweb, WorldCat (OCLC)

Funding: This research received no specific grant from any funding agency in the public, commercial, or not-for-profit sectors.

Conflict of interests: Author has declared that no competing interest exists.

Corresponding author:

Open Access License:

Magda Petrescu, Bd. V. Parvan, no.4, Timisoara 300223, Romania; phone: +40-256-592151; e-mail: imagda2002@ yahoo.com

This is an open access article distributed under the terms of the Creative Commons Attribution-Non-Commercial-NoDerivatives 4.0 International (https://creativecommons.org/licenses/by-nc-nd/4.0/), which permits use, distribution and reproduction in any medium, provided the original work is properly cited, the use is non-commercial and is otherwise in compliance with the license. 


\section{INTRODUCTION}

In university education, the evaluation of students through individual or group projects is an aspect that brings many benefits in teaching, but also has an impact on the graduates' professional careers. Group projects, in which a project team is formed, develops participants' skills such as cooperation, understanding real-life situations, assessing personal skills, integration with other points of view and models. According to the literature, carrying out an educational project means a lot of involvement from the educational actors (teacher, student) as well as effective learning. "Effective learning means reaching a consciously established result and actively involving in achieving it" [1]. The steps to achieve an educational project related to effective learning can be characterized by:

- conscious involvement and participation in the process of building knowledge by establishing links between previous experiences and transposing information into knowledge systems;

- orientation towards achieving objectives established starting from the awareness of the aspects that we intend to change through the project;

- measurable short- and long-term results - project success or sustainability.

In other words, the efficiency in learning and the realization of an educational project appears at the intersection of a coordinate of three elements that need to be in balance: idea, action and result. "Learning efficiency is illustrated by the individual ability to easily, promptly and quickly solve various problematic situations and with increasing difficulty, to face successfully any requests and challenges" [2].

Effective learning through a project involves critical thinking as a tool. Critical thinking is necessary to help a person orient himself in the world of possible alternatives and to become aware of the mechanisms of his/her own thinking [3]. Given the approach of the project from the perspective of learning efficiency, the people involved are:

- active and strategic;

- have an ability to cooperate, dialogue and create knowledge with others;

- can formulate objectives and action plans;

- monitors of the learning process and adaptable to new contexts [4].

Cooperative learning with the help of an educational project aims at making students work interdependently, in groups, to achieve a common goal: solving a problem, exploring a topic, creating new ideas and solutions. It is considered that "cooperative learning is more of an instructional philosophy than a separate method and can be found in the structure of several learning methods and techniques" [5].

The characteristics of cooperative learning are [2]:

- positive interdependence - in cooperative learning performance is collective; students are aware that they can achieve their instructional goals only if their peers also meet their own;

- individual and group responsibility - the group is responsible for achieving its own goals and each member is responsible for his or her contribution to achieving the common goal;

- promoting interaction - students work directly to solve tasks;

- development of interpersonal and group communication skills - involves empowering the student for open and honest communication, conflict management, decision making, mutual trust and leadership of group activity;

- development of group processes - the group decides the usefulness of the actions of each member and establishes the direction to follow in the next steps. 


\section{MATERIAL AND METHODS}

“According to European Commission documents, there are 6,250,000 teachers in Europe, who have a key role to play in helping people develop their talents and potential and acquire the complex knowledge and skills needed for good professional and social integration" [6]. One of the ways in which education can become more efficient is the development and implementation of community projects aimed at improving the problematic aspects of the local community and developing the spirit of community $[7,8]$.

In the present study, in order to ensure the descriptive delimitation of the investigated reality, we choose the educational project as a method. In this context, we considered it appropriate to maintain a qualitative trend in the processing and interpretation of results. The participants in the study are students from the West University of Timișoara, specialized in Physical Education and Sports, enrolled in the teacher training program, 2nd level (master's program students), grouped in five project teams (G1, G2, G3, G4, G5). The students had to carry out a project for the implementation of an educational program in an educational institution or for the local community.

The structure of the project involves:

1. Title (possible acronym)

2. Motivation of the chosen problem, justification of the project (current stage of the project problem) importance of the educational project, originality of the project, impact of the project on the institutional development, references to other projects with similar themes)

3. Beneficiaries, target group

4. Project team; partners

5. Project purpose and objectives (logical matrix)

6. Planning project activities, correlated with the objectives, results and responsibilities of the project team members (Gantt chart)

7. Possible risks and solutions

8. Project budget: human resources (salaries); mobility; procurement; other expenses), the amounts related to each category and the justification of the expenses

9. Monitoring and evaluation of the project - each activity is mentioned in a concrete way and the finality and date of its realization are presented.

10. Dissemination of results: to whom? In what context? In what form?

11. Project sustainability

12. Solutions and discussions

\section{RESULTS}

\section{Educational Project G1 - "Obesity in Students"}

Objective 1 - To identify the factors that lead to students' overweight in correlation with low school performance;

Objective 2 - Harmonious psychomotor development of students through physical activities (appropriate to the group of children or in some cases individual physical activities);

Objective 3 - To form positive attitudes in the educational community (students, teachers, parents, specialists in the field) towards the concept of healthy diet.

Project justification. Obese children face difficulties in terms of social relationships and this leads to poor school performance, because communication and achievement skills as well as student behaviour influence their school work. Thus, girls who have a normal 
weight when they start school but become overweight along the way have poorer results in certain subjects such as math. In overweight boys, however, a higher absenteeism from school predominates. At the same time, low self-esteem appears in obese students, which is a good reason for isolation.

The lack of information on healthy diets appears since the beginning of school, because meal times change, which leads to increased levels of obesity among students and affects the teaching process, leading to lack of performance and poor results. Insufficient number of specialists in this field lead to the inability to identify all cases of obesity among students and the lack of awareness of children about their health problems. Thus, early undiagnosed obese children and the lack of proper training to maintain optimal weight continue to increase the level of obesity among students.

The absence of a compulsory course on healthy eating does not oblige teachers and school management to be directly involved in children's health problems. The existence of fast food stores in the school perimeter encourages students to have access to unhealthy food that has a consequence of increasing the obesity rate.

The objective of the project. Forming a positive and responsible attitude towards weight, healthy diet, harmonious emotional and mental development, knowing the content of education for society, carrying out activities related to nutrition, obesity, weight and rules, necessary for the integration of obese students into social life.

From the proposed activities we can mention training courses for teachers and students, such as "Concepts for a healthy diet", "Let's eat right", "ABC-nutrition"; meetings with specialists for exchanging experiences in school ("My weight", "What? How? When and how do we eat?"); workshops with nutritionists and specialized medical staff in which both students, teachers and parents participate; a fair with healthy and organic food.

To disseminate the results, a website will be created (obezitatealaelev.com), a Facebook account, a group that will contain information about the content of the project, about the activities within the project, as well as other information about obesity and healthy eating. All this information will be accessible after the completion of the project.

\section{Educational Project G2 - "MOdern Playground fOR SCHOOL STUdents"}

Objective 1 - Efficient use of breaks between classes through recreational and fun physical activities performed by students in the modern playground;

Objective 2 - Increasing the degree of socialization between students by using the playground in school in non-formal activities.

Project justification. The central idea of the project is that a well-thought-out and welllocated playground appropriately stimulates creativity and social interaction between students of different ages. The playground will be modern and adapted for the students of the school, which can be used by them both during breaks and outside school hours. The causes of the lack of a playground are multiple and complex.

The lack of a playground for students has a direct effect on the degree of socialization between them. Given the evolution of technology, it is easy to see how students take breaks in small groups and use mobile phones more individually. The degree of interaction between them is extremely low, being little stimulated interpersonal social skills, just at the age when they should be in full development. 
Another cause of this problem is the lack of initiative of students in this regard. The students in the school do not put pressure in the sense of obtaining a playground adapted to their needs. The main reason is that students do not know how they could organize themselves to apply for such investments for their benefit. Finally yet importantly, the lack of parental initiative is another cause of this problem. Parents do not communicate and, although everyone considers a children's playground to be beneficial at the individual level, they do not take any initiative at the group level. None of the groups listed have concrete ways to organize, meet and discuss issues relevant to the school.

Therefore, the project seeks to address these issues by identifying and developing ways of communication between decision-makers and school funders to ensure better funding for the school in relation to current and long-term needs. One of the project goals is the development of communication channels between parents, but also between them and other educational partners, in order to identify the most important needs of the school community. Another goal of the project is to develop students' coordination and collaboration skills to achieve a common goal. The project will be a pretext to create the necessary communication channels between educational partners, but also the skills and habits of using them.

The objective of the project is to increase the degree of quality socialization among school students. "By carrying out this project we will have in our school a modern playground adapted to our times, which can be used by students both during breaks and after classes or extracurricular activities, and which will help increase the degree of socialization between students".

From the project activities, we signal:

Student-centred activities. Student-centred activities that teach pupils what rights and needs they have, how they can capitalize on them in relation to other educational partners, but also how they can use the playground to develop their socialization skills. ("Workshop for children's rights" or workshops such as "Mediation of conflicts", "Financial education", "With socialization at play").

Parent-centred activities. The project will also develop two sets of parent-centred activities, through which they will acquire knowledge about school funding and negotiation between educational partners and, last but not least, for the use of communication channels between parents and teachers (workshops, parent-student-teacher meetings).

Teacher-centred activities. Teachers have an opportunity to participate in courses "Identifying the needs of the school community", "Financing schools", workshops such as "Playground and learning".

Activities for arranging the playground. The arrangement of the playground involves both the purchase of furniture and toys, as well as their installation, this being included in the purchase price.

Dissemination of the project. The project will be disseminated on the school's website and on social networking sites. The project team will create and manage the accounts on the social pages of the project and will ensure good information of students, parents and teachers. All project activities will be announced on the school notice board. Meetings and visits with the business environment will be organized for the signing of partnerships and sponsorship contracts necessary to obtain funds. 
The project has a high degree of sustainability. After the end of the project, the studentparent-teacher communication groups will continue to discuss through classic or modern communication channels (Messenger, WhatsApp), identifying problems and developing solutions. Also, the playground arranged within the project will be able to be used by students, both in school and extracurricular activities. After the completion of the project, the maintenance of the playground will be achieved through funds attracted from the business environment and continuing to sign partnerships and sponsorship contracts.

\section{EDUCATIONAL PROJECT G3 - "SUMMER SCHOOL THROUGH PHYSICAL AND FUN ACTIVITIES"}

Objective 1 - Development of students' physical abilities during the activities of a summer school.

Objective 2 - Reducing the time spent by children in front of the TV / Computer / Telephone and replacing them with various and captivating activities adapted to their age and preferences.

Project justification. The project is addressed to students and parents, so that during the holidays children can benefit from sports activities under the guidance of specialized teachers, for 4 to 6 hours a day, thus eliminating the big problem of most parents, namely to spend a lot time in front of TV and/or computer.

It was found that, in the absence of a sports discipline or a program with various imposed or fun activities, the time that a child can spend in front of a screen (computer, phone, internet) is unlimited if we do not intervene. On vacation, a child without a predetermined schedule wakes up late and gets bored. While looking for refuge in front of the TV, buttoning on different channels, talking on social networks with colleagues or friends, the child forgets about him/herself or does not notice the passage of time.

In families where both parents work from morning to afternoon and are not available to take their children to various activities, their children spend their time as they know best, namely in front of the TV or chatting via a computer. Some parents are disinterested in their children's physical activity because most of them are unaware of the benefits that sports or any other physical activity can bring to their children's lives, so their children end up spending their time in front of the TV or the computer. Other reasons why children stay on TV or computer for too long on holidays is the lack of adequate infrastructure for sports activities. Many towns do not have land and gyms available to children; most of them are private or inside schools where the gates are closed on vacation. This adds to the lack of sport specific facilities and work materials: not all children have rollers or bicycles, balls and rockets or other objects necessary for physical activities.

Limiting access to the online environment is considered necessary because a lot of information is inappropriate for a certain age. On the other hand, the stay of the child in front of a screen for several hours creates a state of safety for worried parents, but the child becomes sedentary due to the lack of physical activity, develops addiction to this, later becoming overweight.

The objective of the project. Reducing children's time on TV / computer through a variety of physical activities suited to children's preferences and providing age-appropriate captivating information.

Project activities. Workshops for teachers of different sports and selection of sports instructors for the summer school (teachers for: cycling, swimming, aerobics, tennis, other sports and games, but also creative activities). Workshops for parents with invited experts in psycho-pedagogy, transposition of online activities into sports activities. 
Dissemination of results is done by creating a website but also a page on social media (Facebook, Twitter, LinkedIN, Instagram, eTwinning), containing a description of the project, the program, the activities related to the project, as well as other important information up to date on the project and, last but not least, a guideline for teachers. The information about the achievements and results of the project, its good practices and the feedback of the participants will be presented with pictures, videos from the project brought to the attention of the general public on the same social media channels but also through mass media (TV, radio, newspapers).

\section{Educational Project G4 - "Adapted Physical activities"}

Objective 1 - To identify exercises and physical activities adapted to each child with special needs;

Objective 2 - To develop positive attitudes of all children in school towards issues related to social inclusion.

Project justification. This project is aimed for children with disabilities such as Down syndrome, autism, etc. It is considered that these children need more attention in physical education and sports classes; in many situations teachers cannot devote enough attention to these children and cannot provide enough support every time. It is welcome to include two hours of adapted physical activity per week. These classes should take place outside of class hours, under the supervision of physical education teachers in the school but also of a physiotherapist.

The project aims to develop motor skills, competitive spirit and the pleasure of exercise, so that when they are in physical education they do not feel marginalized or excluded because they are not as kinesthetically fast as others. In addition to the goals of physical development at normal parameters, the project has as a secondary goal: social inclusion.

Proposed activities include training courses in the field of Special Educational Needs to support teachers, a competition for hiring support teachers, practices conducted by physical education teachers and supervised by experts, conducting extracurricular classes under the supervision of a physiotherapist, analysis of student performance, reassessment of student behavior, a charity event and sports, running, dedicated to children with Special Educational Needs.

Dissemination of results. This project is designed as a model to follow for all schools, for a better relationship between teachers - Special Educational Needs students - other students.

Given that this program takes place during the school year, it is desired that the County inspectorates implement this type of physical education classes after adapting them to compulsory school curriculum, because each school has this type of students. With the parents' consent, a video would be created to promote these activities and popularize them in all schools that face the problem of integrating students with disabilities.

\section{Educational Project G5 - "COMMUNity CUltURAL-SPORTS CENTER"}

Objective 1 - Increasing the interest of school students in participating in extracurricular activities;

Objective 2 - Involvement of both the school and the community in cultural and sports activities.

Project justification. A cultural-sports center will be established by the teachers of the local school with the help of the local administration, which comes to support this project, 
by providing the school with two rooms in the Cultural Centre building, in the immediate vicinity of the school. Here is also an asphalt field that will be arranged and used for the purpose of a multifunctional sports field and as a platform for outdoor cultural activities.

This center will host various activities of the club (sports, folk dance, conservation and reconstruction of traditions and customs popular picture circle), symposia at the community level, painting exhibitions and other exhibition materials, sports and artistic competitions intercommunity and interethnic, reconstructions of local traditions and customs. Following the implementation of the project, the center will permanently represent a nucleus of collaboration both at school and at the community level. The project plan is made up of activities whose results will affect as large a group of direct and indirect beneficiaries as possible.

By implementing this project, together with students, different social categories (parents, adolescents, socially disadvantaged categories, Roma children) will be engaged, so that this center becomes a framework of inter-relationship at the community level, and the school is the coagulating factor of these relations. The project aims to increase the interest of school students in the community to participate in extracurricular activities, as well as the development of cultural-sports extracurricular alternatives at the level of the school and the community of which it is part.

Project activity. Arranging the space of the sports cultural center; providing necessary equipment for extracurricular activities; creating circles and activities, sports competitions (chess - "Minds", table tennis - "Movement and health", badminton - "Spring Cup"); cultural activities ("Commune between past and future", "Commune Day").

Dissemination of results. Creating a Facebook page in order to promote the activities and disseminate the results resulted from the implementation of the project. Inauguration of the sports cultural center, posters, invitations, leaflets, brochures - promotion and media coverage to the community. All sports competitions and artistic developments will be covered by posters, leaflets, distributed in the school and in the community, invitations will be offered to guests of honor. The photos taken by the children at these events will be displayed on the school panel. The exhibition activities and the students' paintings will be promoted and publicized through the internet, posters, leaflets, at the community level and outside it.

After the end of the project, this space which is arranged to carry out extracurricular activities will continue to host these types of activities. In this location, there will be rehearsals for future cultural events and training for sports competitions. The rehearsals for folk dances will continue, the already formed bands will perform on various occasions celebrations, artistic competitions at school, in the community and outside the community, at folk festivals. In addition to the Romanian and Roma dance groups, we are considering the expansion of the Hungarian ethnic group, whose percentage is significant in the locality. Also, through the Facebook page will continue to be promoted the dissemination of the activities of the Sports Cultural Centre.

\section{CONCLUSIONS}

Education and the school, as its main institution, face problems specific to contemporary society, problems with a wide range of action, from the general, planetary level to the local, community level. When educating students, teachers can appeal to effective learning methods, but at the same time they can implement other activities such as educational projects. Students can thus find problem situations, think critically and practice how they could improve their activity in a school. 
Thus, students become ready to appeal and graduate from the implementation of educational projects. It can be stated that the ways in which the school action can become more effective is the development of these projects by teachers whose objectives are to improve the problematic aspects at the level of the school institution and the local community and the development of the spirit of belonging.

This study has an obviously limitation to these case studies, used only as examples of the way students (future sport teachers) can be involved into projects with effective learning. A possible way for further research on this topic can be developed by involving the students as subjects into a qualitative focus-group interview about their work.

\section{REFERENCES}

[1] Bernat SE. Tehnica învăţării eficiente [Effective learning technique]. Cluj-Napoca: Presa Universitară Clujeană; 2003. Romanian.

[2] Dumitru IAl. Dezvoltare agândirii criticeş iînvăţarea eficientă [Developing critical thinking and effective learning]. Timişoara: Editura de Vest. 2000. Romanian.

[3] Bernat SE, editor. Formator perfecţionare - manual ul cursantului [Advanced trainer - the student's manual]. ClujNapoca: Risoprint; 2010. Romanian.

[4] Harkai G.Un cadrumetodologicînsprijinulfacilităriiînvăţăriieficiente [A methodological framework in support of facilitating effective learning]. In Domilescu G, Harkai M, Ilie M, Petrescu M, Tîru CM.Profesorul facilitator sau cum săfii cu adevărat un profesormai bun pentrueleviităi [The facilitator teacher or how to really be a better teacher for your students].Timișoara: Eikon; 2012. Romanian.

[5] Negreţ-Dobridor I, Pânişoară IO. Ştiinţaînvăţării: de la teorie la practică [The science of learning: from theory to practice]. Iaşi: Polirom; 2005. Romanian.

[6] Domilescu G. Cadrul didactic - facilitator al dezvoltării comunita redurabile [Teacher - facilitator of sustainable community development]. In Domilescu G, Harkai M, Ilie M, Petrescu M, Tîru CM.Profesorul facilitator sau cum săfii cu adevărat un profesormai bun pentrueleviităi [The facilitator teacher or how to really be a better teacher for your students].Timișoara: Eikon; 2012. Romanian.

[7] Enache R. Management ul proiectelor educaționale [Management of educational projects]. București: EdituraUniversitară. 2019. Romanian.

[8] Ulrich C. Învățareaprin proiecte [Learning through projects]. Iași: Polirom; 2017. Romanian. 